ISSN 1996-1073

www.mdpi.com/journal/energies

Article

\title{
Offshore Antarctic Peninsula Gas Hydrate Reservoir Characterization by Geophysical Data Analysis
}

\author{
Maria Filomena Loreto *, Umberta Tinivella, Flavio Accaino and Michela Giustiniani \\ National Institute of Oceanography and Experimental Geophysics-OGS/Borgo Grotta Gigante, \\ 42/C Trieste, Italy; E-Mails: utinivella@ ogstrieste.it (U.T.); faccaino@ogs.trieste.it (F.A.); \\ mgiustiniani@ogs.trieste.it (M.G.)
}

* Author to whom correspondence should be addressed; E-Mail: mfloreto@ogs.trieste.it; Tel.: +39-040-214-0340; Fax: +39-040-214-0340.

Received: 8 December 2010; in revised form: 21 December 2010 / Accepted: 24 December 2010 / Published: 31 December 2010

\begin{abstract}
A gas hydrate reservoir, identified by the presence of the bottom simulating reflector, is located offshore of the Antarctic Peninsula. The analysis of geophysical dataset acquired during three geophysical cruises allowed us to characterize this reservoir. $2 \mathrm{D}$ velocity fields were obtained by using the output of the pre-stack depth migration iteratively. Gas hydrate amount was estimated by seismic velocity, using the modified Biot-Geerstma-Smit theory. The total volume of gas hydrate estimated, in an area of about $600 \mathrm{~km}^{2}$, is in a range of $16 \times 10^{9}-20 \times 10^{9} \mathrm{~m}^{3}$. Assuming that $1 \mathrm{~m}^{3}$ of gas hydrate corresponds to $140 \mathrm{~m}^{3}$ of free gas in standard conditions, the reservoir could contain a total volume that ranges from 1.68 to $2.8 \times 10^{12} \mathrm{~m}^{3}$ of free gas. The interpretation of the pre-stack depth migrated sections and the high resolution morpho-bathymetry image allowed us to define a structural model of the area. Two main fault systems, characterized by left transtensive and compressive movement, are recognized, which interact with a minor transtensive fault system. The regional geothermal gradient (about $37.5^{\circ} \mathrm{C} / \mathrm{km}$ ), increasing close to a mud volcano likely due to fluid-upwelling, was estimated through the depth of the bottom simulating reflector by seismic data.
\end{abstract}

Keywords: BSR; CIGs; velocity model; gas estimate; bathymetry; tectonics; Antarctic Peninsula 


\section{Introduction}

Gas hydrates are solids composed by ice containing molecules of gas, usually methane, in the lattice which grow within the pore space of sediments [1]. They are common in the upper hundred meters of sediments along both active and passive continental margins [2] and permafrost areas [3] and where high pressure, low temperature and adequate gas saturation fall within stability conditions [1]. In seismic sections, the presence of gas hydrate within marine sediments is underlined by the Bottom Simulating Reflector (BSR). The BSR is a reflector that mimics the seafloor and it is characterized by reverse phase with respect to the seafloor [2]. Generally, the BSR is given by the result of strong acoustic contrast produced by the free gas accumulated at the base of the gas hydrate layer [4-6]. Sometimes, it can also be the result of high gas hydrate accumulation within sediments without free gas below it [6].

During last decades, the scientific community has employed many resources in studying gas hydrates in order to evaluate their potential as a future energy resource [7-9], their geological hazards [10], and their possible influence on carbon cycle within oceans [11,12] contributing to the global warming [13,14]. Moreover, due to recent hydrocarbon fuel resource crisis, interest in gas hydrates has increased strongly [15].

Some authors have pointed out how geological and environmental features can affect gas hydrate accumulation within marine sediments, even when stability conditions and adequate gas amounts are respected. In particular, the Bottom Simulating Reflector (BSR) identification is affected by geological features. In fact, presence of important faults (normal or inverse) acting as main conduit for fluid escapes $[16,17]$ and sediments stratification parallel to the seafloor can make difficult the interpretation of the BSR [18]. Around several mud volcanoes, the gas hydrate distribution is strongly influenced by the thermal field [19]. Finally, the depth of hydrate stability zone can be affected by the fluid salinity changing the depth and/or generating a focused flux of gas that can reach the seafloor [20].

Many approaches developed by different authors are available to quantify gas-phase amount presents within sediments. Some procedures require direct measurements in order to estimate the gas hydrate contents, such as water chlorinity analysis [21,22]. Other procedures are based on seismic data analysis, using velocity seismic models and/or amplitude variations versus offset analysis [23-25]. Moreover, some authors have suggested modelling elastic velocities versus gas hydrate concentrations using seismic velocities [26-28] or sonic log data [26,29] to obtain information about the hydrate occurrence.

In our study area (offshore Antarctic Peninsula), several Multi Channel Seismic (MCS) profiles, gravity cores and multibeam data were acquired from 1990 to 2004 [30]. We performed iteratively pre-stack depth migration (PreSDM) and analysis of Common Image Gathers (CIGs) to obtain a reliable velocity field. The theory developed by Tinivella [26] was adopted to estimate gas hydrate amount, because no direct petro-physical parameters were available. 


\section{Geological Setting}

The investigated area is located offshore Elephant Island in the South Shetland margin. The area extends from $60.5^{\circ} \mathrm{S}$ to $61.5^{\circ} \mathrm{S}$ and from $56^{\circ} \mathrm{W}$ to $58.5^{\circ} \mathrm{W}$ (Figure 1). In this area, the continental margin shows a complex tectonic setting due to the subduction of the Antarctic and the "former Phoenix" plates beneath the South Shetland micro-continental block. The Phoenix plate is the last remnant of the Nazca plate subducted beneath the Antarctic plate and bordered by the Hero Fracture Zone, to the SW, and by the Shackleton Fracture Zone (SFZ) to the NE. Nazca plate subduction was active along the Pacific margin of Gondwanaland from late Paleozoic time [31] to $4 \mathrm{Ma}$ ago [32], when spreading at the Antarctic Phoenix ridge ceased [33]. Currently, the subduction process is controlled by sinking and roll-back of the oceanic plate. This passive subduction is coupled with the extension of the Bransfield Strait marginal basin [32,34-36].

Figure 1. Shaded relief of low resolution bathymetric data downloaded by the website at [37]. Mercatore projection is adopted. Thick white arrows indicate a schematic NW-SE extension across Bransfield Basin (B.B.). The direction of the subduction "Former" Phoenix Plate is indicated with thin white arrow, while transform fault movements are indicated with double white thin arrows. The dashed rectangle indicates the analyzed area. Location of seismic lines analysed in this work are indicated as thin solid lines; the thick lines refer to the line shown in Figures 2, 4 and 5. E.I.: Elephant Island; F.T.P.: Frontal Thrust Prism; S.S.I.: South Shetland Islands; S.F.Z.: Shackleton Fracture Zone.
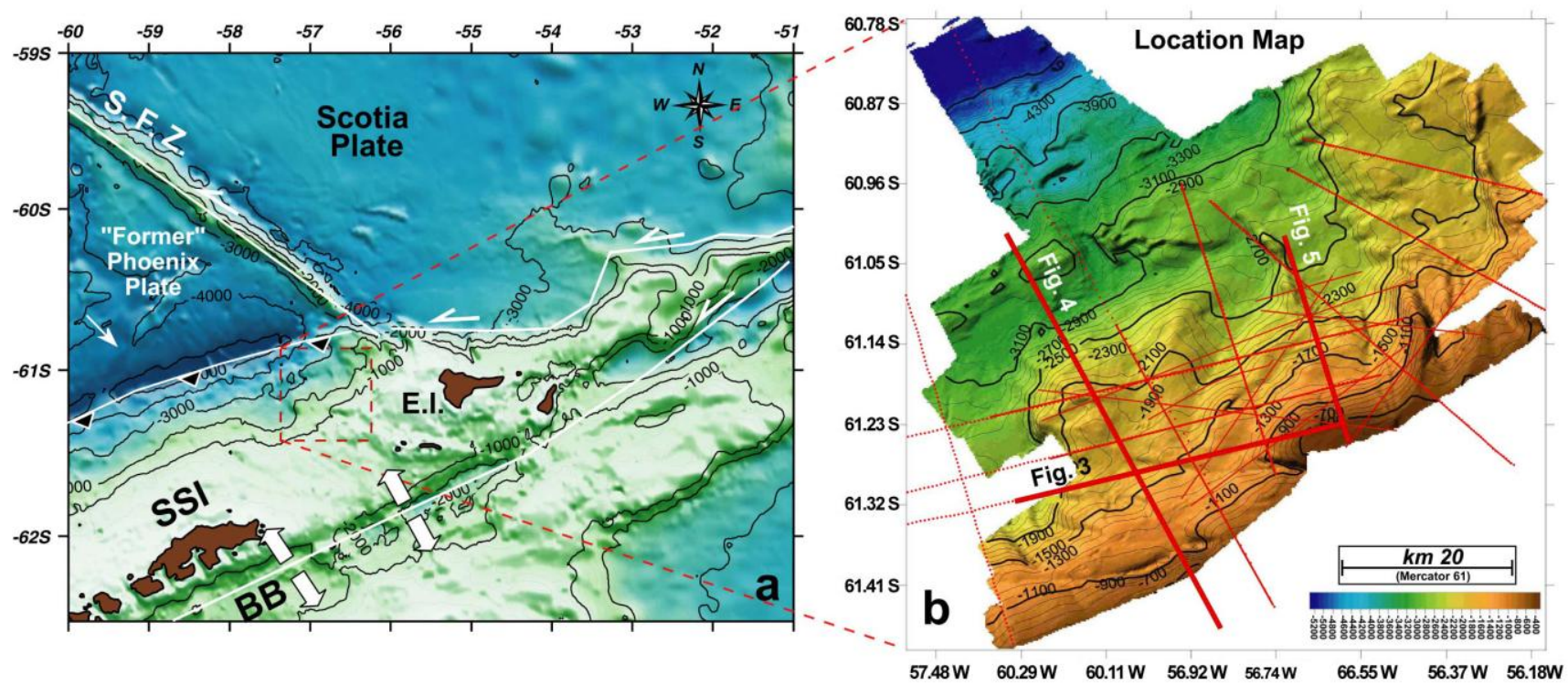

The SFZ along the northeastern side is still active [38], whereas the Hero Fracture Zone along the southwest side is locked [39]. The surface traces of these two main fracture zones delimit the lateral extent of the Bransfield microplate [40], which separated from the Antarctic Peninsula by opening of the back-arc basin related to the ridge spreading cessation [41].

From the interpretation of time migrated seismic profiles (see Figure 1), a preliminary tectonic setting was delineated [42]. Identified a sedimentary prism affected by several thrust faults and extensional faults, oriented sub-parallel to the continental shelf, and the presence of a strike slip fault 
related to the Shackleton Fracture Zone. This fault crosses the entire continental slope splitting the margin in two parts with different characteristics. To the northeast of the fault, a strong and continuous BSR is detected, while to the southwest it becomes weak and discontinuous. Moreover, small mid-slope basins are common within the prism, often bounded by extensional faults that reach the seafloor locally.

\section{Geophysical Data}

The geophysical data were acquired during three geophysical surveys. Eleven seismic profiles with long streamer and one Ocean Bottom Seismometer (OBS) data were acquired during the first two surveys, carried out in the 1989/90 and 1996/97 Austral summers [23,43], and several geophysical data were acquired in the 2003/04 Austral summer [30].

During the first survey, the energy source was composed of two arrays of 15 air-guns (total volume of $45 \mathrm{~L}$ ), fired every $50 \mathrm{~m}$. The streamer was $3000 \mathrm{~m}$ long with 120 channels and $25 \mathrm{~m}$ hydrophone group interval. The sampling interval was $4 \mathrm{~ms}$. During the second survey, the same streamer was adopted, while the source consisted of two generator-injector guns with a total volume of $3.5 \mathrm{~L}$ firing every $25 \mathrm{~m}$. The sampling interval was $1 \mathrm{~ms}$. Figure 1 shows the dataset here analysed. The data are characterised by high signal/noise ratio requiring just the application of pass-band filter.

In the last cruise, multibeam data were acquired by using the Reson Seabat 8150, which is an Ocean Depth Multibeam Echo Sounder System. The system is characterized by nominal depth ranging between 0.1 and $15 \mathrm{~km}, 234$ beams and nominal frequency of $12 \mathrm{kHz}$. Data acquisition and processing were performed using PDS2000 software (RESON). The high-resolution morpho-bathymetry image is characterized by $150 \mathrm{~m}$ cell size. Moreover, sub bottom profile data $(7 \mathrm{kHz})$ and gravity cores were also acquired [30].

\section{Methods}

In order to characterize the gas reservoir located offshore the Elephant Island, regional velocity and gas hydrate concentration models were developed. We applied depth migration in the pre-stack domain (Kirchhoff algorithm) to determine with a layer stripping approach both the velocity field and the seismic image in depth [45]. In fact, it is well known that pre-stack depth migration provides information about the quality of the velocity field [45]. When an incorrect velocity is used to migrate MCS data, the imaged depths of reflections in a CIG will differ from each other along offset. In this situation, residual move-out is observed in the CIGs; for this reason, residual move-out analysis is used to update the migration velocity [46]. The velocity fields obtained along the 2D seismic lines were then interpolated in order to obtain a 3D velocity model.

First of all, velocity values from $60 \mathrm{~m}$ to $3840 \mathrm{~m}$ were extracted every $40 \mathrm{~m}$, considering a horizontal spatial grid equal to $200 \mathrm{~m}$. We produced the velocity slides interpolating the values by using the GMT software [47]. The adopted interpolation parameters are the following: first step, $3 \mathrm{~km}$ of block dimensions with a $25 \mathrm{~km}$ of research radius; second step, $0.2 \mathrm{~km}$ of block dimension with $2.4 \mathrm{~km}$ of research radius. The output model has a cell grid size of $200 \mathrm{~m}$ in the two horizontal direction and $40 \mathrm{~m}$ in depth. The total nodes are: 241 along the longitude; 309 along the latitude; and 96 in depth. The so-obtained regional velocity model was smoothed along the three axes. The 
reliability of the interpolation was verified comparing the original $2 \mathrm{D}$ velocity section with the $2 \mathrm{D}$ velocity section extracted from the interpolated model. The error estimated in correspondence of the main inverted horizons (seafloor, BSR, and the reflector in between) shows a trend included within the range of $\pm 5 \%$, even if local high error values are also detected (about $\pm 8 \%$; Figure 2).

Figure 2. Percentage error of the interpolated velocities along the line 197214 at the sea floor (SF, stars), the horizon 1 (HOR1; solid triangles), and the BSR (crosses). See text for details.

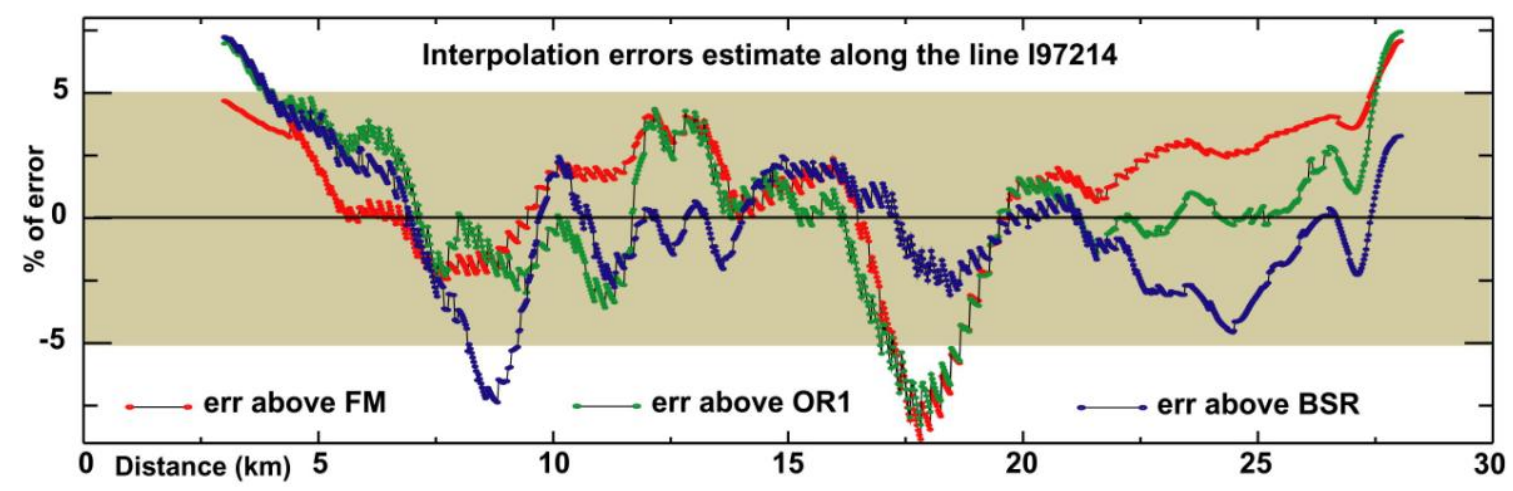

The method for estimating gas hydrate and free gas concentrations consists of comparing seismic velocities with theoretical velocity curves in the absence of free gas and gas hydrate, the so-called reference velocity profile. For this purpose, we used the methodology described in [26] and already tested in this area to quantify the gas hydrate and the free gas in the pore space [24]. Essentially, the concentration of gas hydrate was estimated by using the modified Biot-Geerstma-Smit theory [26], which translates the velocity anomalies, calculated with respect to a reference curve, in terms of gas amount.

Using the seafloor depth and information from literature $[23,48]$, the reference velocities (i.e., the velocity of water saturated marine sediments) were evaluated. We used as reference curves the Hamilton curves $[49,50]$. We used the average Poisson ratio for all sediments equal to 0.435 , obtained by OBS data analysis in the same area [23].

\section{Analysis of the Seismic Data}

\subsection{Data Analysis}

We obtained information about the geometries and the velocities of the main geological structures from the PreSDM sections. The velocity model was obtained by using the PreSDM (Kirchhoff algorithm) with a layer stripping approach. The method uses the output of the PreSDM performed at different offsets (the CIGs) to determine iteratively the velocity field [45,46]. After the PreSDM, the correctness of the migration velocity is verified by the analysis of the flatness of reflections in CIGs domain. If the reflectors in the CIGs are not flat, a residual moveout analyses is required to correct the curvatures of reflections. The energy in the semblance is quantified by residual $(r)$ parameter, which is a measurement of the flatness deviations along the offset. If the $r$-parameter has a negative value, it means that the velocity needs to be increased, whereas it needs to be decreased for positive value. The 
seismic processing was performed by using the open source Seismic Unix software (SU; [51]) and home codes created ad hoc [30].

The initial velocity model had uniform velocity equal to $1465 \mathrm{~m} \cdot \mathrm{s}^{-1}$ and a $20 \mathrm{~m}$ vertical spacing; while the horizontal spacing was calculated for each profile and ranged from 25 to $27.25 \mathrm{~m}$ in order to avoid errors introduced by irregular ship velocity. After a few iterations, the velocity of the first layer (sea water) was fixed. Below the seafloor, the more continuous reflector located between the seafloor and the BSR was analysed. 5 iterations were required to invert the velocity of the second layer, while the velocity above the BSR was defined after an average of 20 iterations. The final PreSDM was performed introducing a velocity gradient equal to $0.6 \mathrm{~s}^{-1}$ below the BSR and smoothing the whole velocity field.

\subsection{Structural Analysis}

Seven PreSDM sections are analysed to obtained information about geological structures and the velocities. The most representative of them, because they show the main geological features of the area (see thick lines in Figure 1), are here analysed.

Figure 3 shows the depth image of line 197209, obtained by using the methodology described above, on which the interpretation and the velocity model are superimposed. The SE sector of the seismic section, between 7 and $14 \mathrm{~km}$, shows a flat seafloor in correspondence of which a well stratified and folded sedimentary sequence is abruptly interrupted. At about $15 \mathrm{~km}$, a strong variation of seafloor depth is present (about $750 \mathrm{~m}$ ) related to the presence of a fault, as well as imaged in the morpho-bathymetry (Figure 4). At about $28 \mathrm{~km}$, a second discontinuity, which affects the seafloor and slightly deforms sediments, is detectable. As can be seen on Figure 4, an evident morphological expression on the seafloor is detectable. The two above-mentioned faults could be part of the same faults system showing a transcurrent character, and called Transcurrent Fault System 1 (TFS1; Figure 4). Between 37 and $47 \mathrm{~km}$, the sediments are deformed forming an anticline. The NW part of the line is shaped by a trough wide about $1.2 \mathrm{~km}$, also detectable in the morpho-bathymetric map and showing a NE-SW trend.

Figure 5 shows seismic image of line 197213, with superimposed the interpretation and the velocity, located in-line to the continental margin. Between 0 and $14 \mathrm{~km}$, three discontinuities are recognizable. One of them, the most important, abruptly deeps the seafloor of about $400 \mathrm{~m}$ (at about $9 \mathrm{~km}$ ) and border a filled channel. The others two discontinuities with the same trend (normal faults) are evident at 12 and $13 \mathrm{~km}$. In the morpho-bathymetric map, these faults show variable trend from NNW-SSE to N-S. These faults are likely part of a minor fault system called secondary Fault System (s-FS). In the central part of the line, at about $19 \mathrm{~km}$, a transtensive fault is identified by a small bathymetric variation and by the deformation of sediments. These faults are likely part of the TFS1 already identified in the line 197209 (Figure 3) and in the morpho-bathymetric map (Figure 4). Toward the NNE (at about $32 \mathrm{~km}$ ), a sedimentary basin, about $1 \mathrm{~km}$ depth and $5 \mathrm{~km}$ wide, is present at the top of a folded unit. 
Figure 3. PreSDM section of line I97209, on which the velocity model is superimposed. Thick red lines: main faults. Dashed red lines: minor fault and fractures. The BSR and the main geological features are reported. TFS1: Transcurrent Fault System 1; Vertical exaggeration 1:4; Crossing lines are indicated.

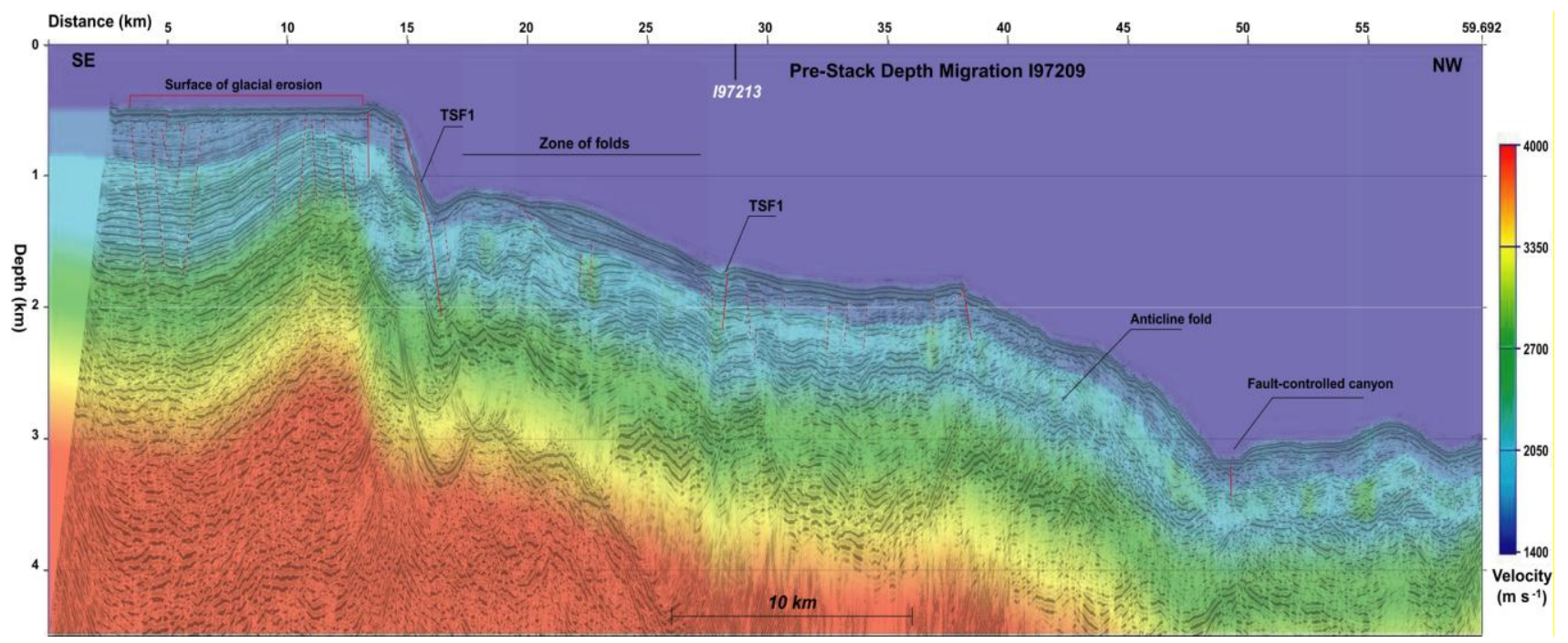

Figure 4. Shaded relief integrating seismic profile interpretations and morpho-bathymetry information. The recognized fault systems are indicated with thick red lines; minor faults and fractures are indicated with dashed red lines. White arrows indicate slumps; light blue arrows indicate the recognized mud volcanoes; and black thick arrows indicate a submarine canyon. Anticline and sharp folds are indicated with green symbol. s-FS: secondary Fault System; TFS: Thrust Fault System; V.V.: Volcano Vualt.

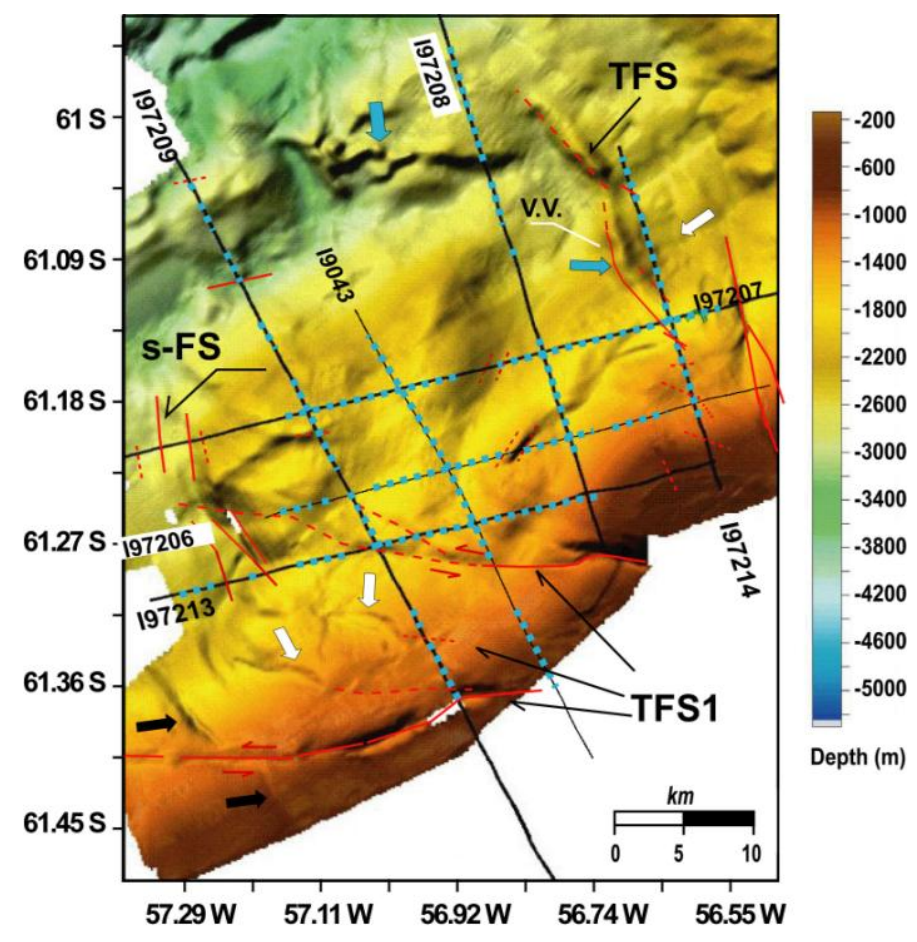


Figure 5. PreSDM section of line I97213, on which the velocity model is superimposed. The s-FS, the TFS1, the BSR and the main geological features are indicated. Vertical exaggeration 1:4. Minor faults (red dashed lines) and major faults (red thick lines) are indicated. Crossing lines are reported.

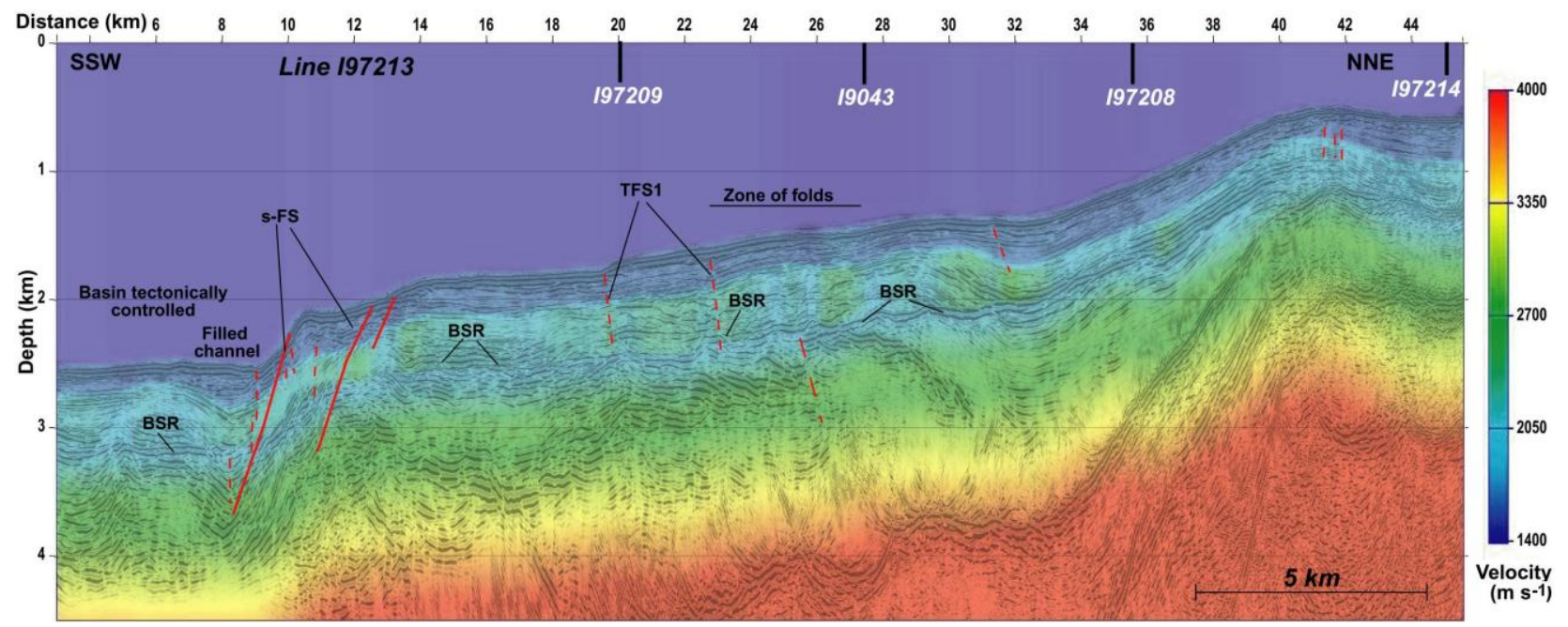

Figure 6 shows seismic image of line I97214, with the interpretation and the velocity model superimposed. Between 5 and $13 \mathrm{~km}$, shallow stratified sediments deepen ocean-ward with an on-lap closure at the top of an anticline structure. This structure soles out at the top of a thrust fault, located around $15 \mathrm{~km}$ and confined below the seafloor. Along the section, several minor faults and fractures affecting the sediments are detectable. Between 15 and $18 \mathrm{~km}$, another minor structure is imaged in the seismic line. This anticline structure are located to the southern end of a mud volcano, called Vualt [30], and clearly identified on the morpho-bathymetry image (light blue arrow in Figure 4). Between 19 and $28 \mathrm{~km}$, the sediments are well stratified, even if slightly deformed by minor fractures and faults. These faults deepen the basin up to of a maximum thickness of about $450 \mathrm{~m}$ at $26.5 \mathrm{~km}$ (Figure 6).

Figure 6. PreSDM of line 197214, on which the velocity model is superimposed. The BSR and the main geological features are indicated. Fractures are indicated with dashed red lines. TSF: Thrust Fault System; SR_1: Seismic Reflector 1; Vertical exaggeration 1:4; Crossing lines are indicated.

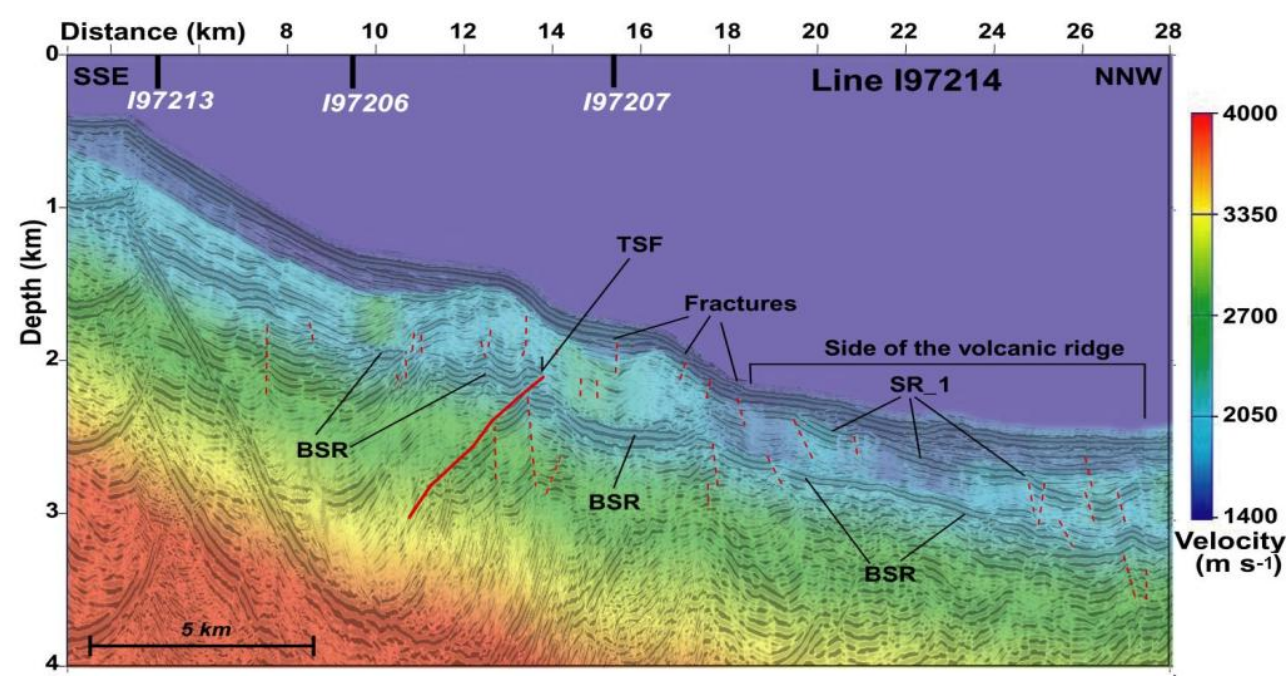


Finally, the analysis of the high resolution morpho-bathymetric map allowed us to recognise important geological features. In addition to the three important fault systems (TFS, s-FS and TFS1), other morphological elements, such as slumps [30], are detected in the southernmost part (see white arrows in Figure 4). A deep canyon is crossed by the TFS1, as evidenced by black arrows (Figure 4). Moreover, some morphological highs, similar to the Volcano Vualt, are present in the northern part, close to the trench (light blue arrow), and even associable to volcanic ridge.

\subsection{BSR Analysis}

All seismic lines reveal the presence of the BSR with variable characteristics along with. In particular, the seismic line 197209 is characterized by the presence of the BSR (Figure 3), which results locally weak and somewhere disappears, as between 27 and $30 \mathrm{~km}$ where an active fault is recognized. The velocity model shows lateral variations, more evident in the third layer. The BSR is evident along the line I97213 (Figure 5) with variable amplitude character, and it is continuous between 20 and $35 \mathrm{~km}$. Between 8 and $20 \mathrm{~km}$, the BSR becomes more discontinuous, in particular close to the fault system s-FS. The velocity field evidences lateral velocity variation in the third layer, showing higher velocity with respect to the velocities observed at the line 197209.

Between $9.5 \mathrm{~km}$ and the end of the line $\mathrm{I} 97214$ (Figure 6), the BSR is locally discontinuous and its depth ranges from 450 to $700 \mathrm{mbsf}$. Seismic velocities are affected by intense lateral variations showing higher values at about 10 and $15 \mathrm{~km}$ (central part of the line), and very low velocity within sediments along the east side of the volcanic ridge, between 18 and $28 \mathrm{~km}$. All the 2D velocity fields are converted in 2D gas hydrate concentration sections. As expected, the concentration variations are consistent with the velocity variations and will be later discussed. In fact, lacking direct measurements, which are necessary to validate the background velocity, only qualitative information about the gas hydrate occurrence can be extracted.

\section{Discussion}

\subsection{Regional Models}

In order to analyse both velocity and gas concentration variations and to identify the link between bathymetry and geological features, regional models are produced. Figure 7 (left) shows the velocity anomalies extracted just above the BSR. This BSR map was obtained interpolating the BSR depths extracted from the 2D seismic models. The area is characterised by an average velocity anomaly of 100-200 $\mathrm{m} \cdot \mathrm{s}^{-1}$. High anomaly values (about 300 and $350 \mathrm{~m} \cdot \mathrm{s}^{-1}$ ) are detectable in the north-western side of the reservoir and within the central area (see black thick arrows). Close to the Mud Volcano Vualt (see yellow thick arrow) very low or zero velocity anomalies are detected. As expected, the gas hydrate concentrations map (Figure 7, right), whose values were extracted just above the BSR, shows a similar trend to that of the velocity anomalies map. The average amount of the hydrate varies in a range of $4 \%$ (white arrows) $-16 \%$ (black arrow) of the total volume, while very low gas hydrate concentration is predicted close to the Mud Volcano Vualt.

Finally, the analysis of the seismic BSR depth can help to understand the meaning of its lateral changes. To do this, the thickness map of the possible gas hydrate zone (Figure 8) by seismic data, 
obtained by using the GMT free software [47], was evaluated. Interpolation algorithm parameters were: first step, $3 \mathrm{~km}$ of block dimensions and $25 \mathrm{~km}$ of research radius; and, second step, $0.2 \mathrm{~km}$ of block dimension and $2.4 \mathrm{~km}$ of research radius. The cell grid size was $200 \mathrm{~m} \times 200 \mathrm{~m}$. The thickness map was obtained performing the difference between the seafloor from multibeam data and the BSR depth from PreSDM. The area that was considered reliable, based on seismic interpretation, extends $600 \mathrm{~km}^{2}$.

Analyzing the possible gas hydrate thickness (Figure 8), local high values, more than $750 \mathrm{~m}$ (see black tick arrows), are detected along the seismic lines 197213 and 197209 . The most part of the reservoir shows values ranging between $450 \mathrm{~m}$ and $600 \mathrm{~m}$. In the eastern side, the thickness is strongly reduced to $300 \mathrm{~m}$ close to the Mud Volcano Vualt (see white thick arrow).

Figure 7. (A) Map of velocity anomalies extracted just above the BSR. Contour lines are plotter every $50 \mathrm{~m}$. White arrows indicate low velocity anomalies; black arrow indicate the high velocity anomalies; and yellow arrow indicate the Mud Volcano Vualt; (B) Map of the gas hydrate amount extracted just above the BSR. Contour lines are plotter every $2 \%$. White thick arrows indicate low gas hydrate amount corresponding to the low velocity anomalies, and black arrow indicates the high gas hydrate amount. A mask is over-imposed on the images to visualize the reliable area. The structural interpretation was over-imposed as red solid and dashed lines.

(A)

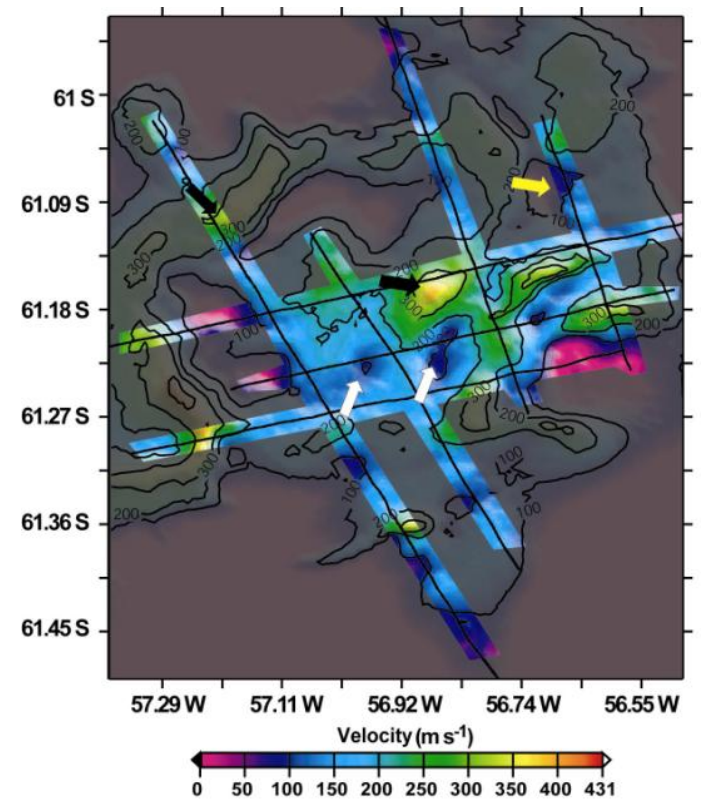

(B)

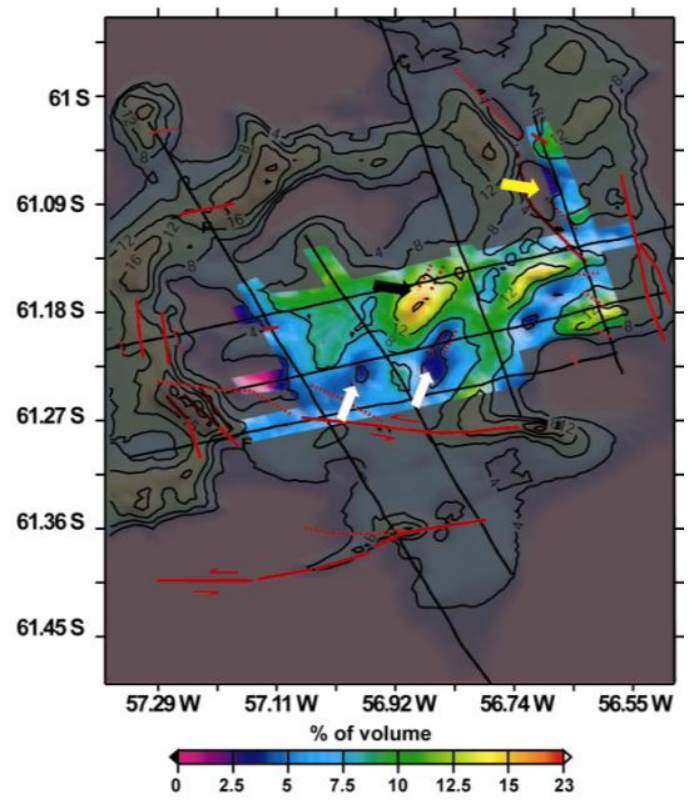

Based on depth models, the regional geothermal gradient is estimated comparing seismic and theoretical BSR depths. Knowing the sea water depth (from the bathymetry), the sea bottom temperature (equal to $0.4{ }^{\circ} \mathrm{C}$ from OBS data; [23]) and considering geothermal gradients from 25 to $45^{\circ} \mathrm{C} / \mathrm{km}$ with a step of 2.5 , the theoretical BSR depth was evaluated along all seismic profiles. Moreover, these evaluations were performed supposing a mixture of gasses: $90 \%$ methane; $5 \%$ ethane; and $5 \%$ propane, as pointed out by core analysis [1,30]. The regional geothermal gradient is estimated fitting the seismic BSR depth with the theoretical one. For this goal, we used the Geographic Information System (GIS). The distribution of estimated geothermal gradients is shown in Figure 9. 
For each available dataset, we created a grid with $200 \mathrm{~m}$ cell size. Then, each grid was subtracted to the grid representing the seismic BSR depth. Considering that the maximum error of the seismic BSR depth is equal to 5\% [24], just values lower than this error was considered in every grid cell. Note that the grids were transformed in absolute value before performing the subtraction.

Figure 8. Seismic potential gas hydrate thickness expressed in mbsf. Contour lines are plotted every $75 \mathrm{~m}$. Black arrows indicate the higher and white arrow indicate the lower BSR depth detected within the reservoir. A mask is over-imposed on the images to visualize the reliable data. The structural interpretation was over-imposed as white solid and dashed lines.

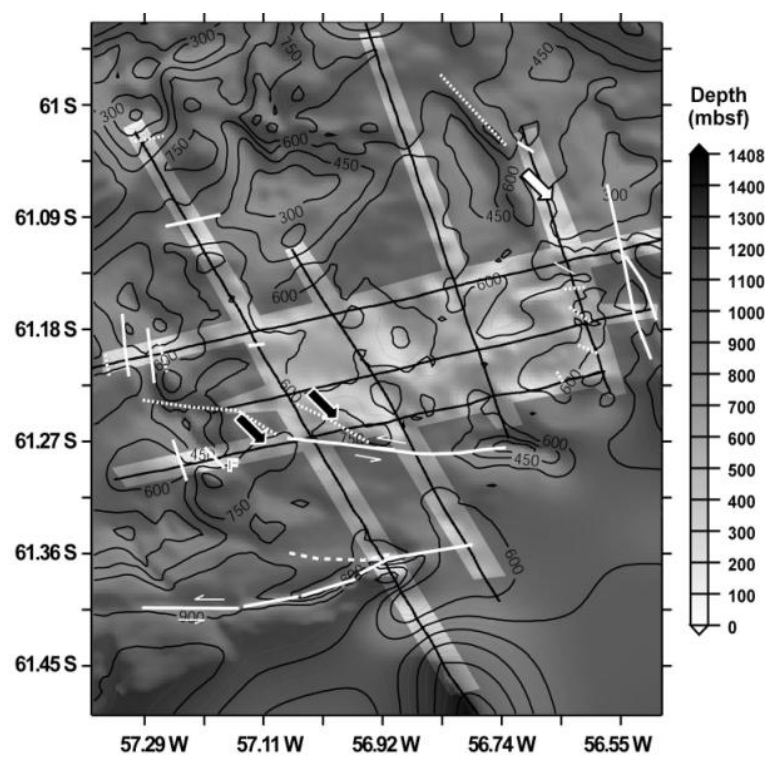

Figure 9. Map of the difference between seismic and calculated BSR depth produced by using the GIS software; see text for details. geothermal gradient equal to (A) $32.5^{\circ} \mathrm{C} / \mathrm{km}$, to (B) $35^{\circ} \mathrm{C} / \mathrm{km}$, to (C) $37.5^{\circ} \mathrm{C} / \mathrm{km}$ and to (D) $40{ }^{\circ} \mathrm{C} / \mathrm{km}$. The mask limits the central area. Black arrows indicate the Mud Volcano Vualt.
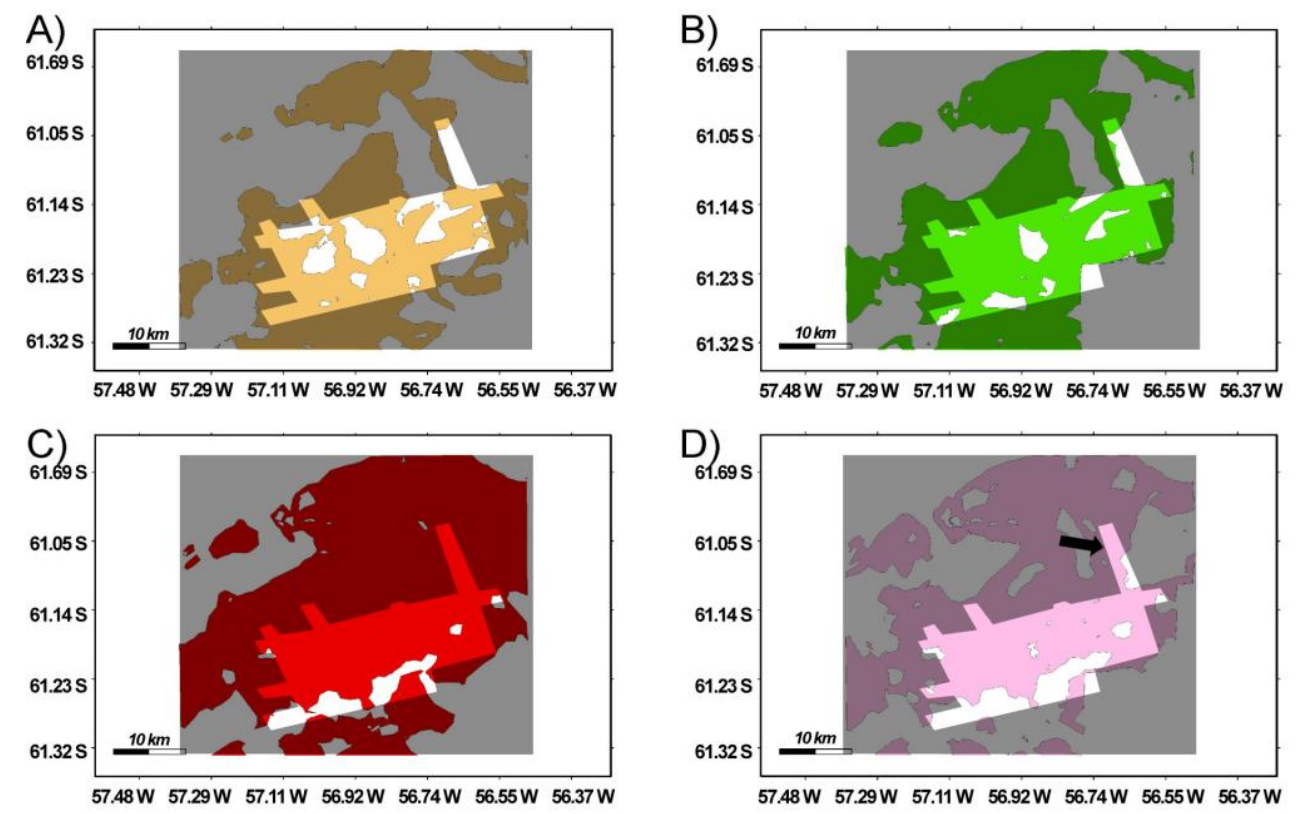
Figure 9 shows highest values of the geothermal gradient located close to the volcanic ridge (black thick arrow). In general, we observed an increase of the geothermal gradient versus the trench. The analysis of these grids suggests that the regional geothermal gradient ranges between 37.5 and $40{ }^{\circ} \mathrm{C} / \mathrm{km}$.

\subsection{Gas Hydrate versus Geological Features}

The main features observed along the seismic lines (Figure 4) are correlated with the main features recognised in the high resolution morpho-bathymetric information. This relation highlights the presence of two main fault systems (TFS and TFS1). The first one was interpreted as a compressive system located at the NE side of the gas hydrate reservoir, while the second one was interpreted as transcurrent system with normal component and bordering the SW side. This system is composed of two main sub-parallel branch faults as detectable on the morpho-bathymetry.

TFS could be associated to the elongated structural high (see blue arrows in Figure 4), characterized by anticline deformation (Figure 6). This element suggests that the entire elongated high could represent a fault-controlled anticline structure.

TFS1 shows a left-movement evidenced by the $2350 \mathrm{~m}$ shift of a canyon, orthogonally orientated with respect to the southern branch fault (black thick arrows in Figure 4). The normal component is determined by the depression that deepens sediments of about $750 \mathrm{~m}$ (Figure 3). The strong reduction or the absence of the normal component along the northern branch fault (see at $28 \mathrm{~km}$ distance in Figure 3) suggests a variable strain along the TFS1. In the SW side of the investigated area, a secondary fault system (s-FS), also characterized by a normal movement, is responsible of a basin formation (Figure 5). The s-FS is affected by the TFS1, as suggested by the change of fault orientations, from NW-SE to N-S, at the west side of the reservoir (Figure 4). The clockwise rotation of the s-FS is in agreement with the left movement of the TFS1, confirming this hypothesis. The narrow trough recognized in the north portion of the reservoir (Figure 3 and 4) could be tectonically controlled. This is suggested by the discontinuity detected in the seismic line 197209 and by the elongate and straight shape, deduced by the morpho-bathymetry image. In the central part of the reservoir, only few and discontinues faults affect the seafloor (Figure 4).

Gas hydrate concentration (Figure 7) is affected by strong lateral variation partially due to the activity of the fault systems (TFS1, TFS, and s-FS). In particular, high gas hydrate concentrations at the BSR, resulting in a range of $4-16 \%$ of total volume, are detectable (the central area). Gas hydrate concentration close to TFS 1 is in a range of $0-6 \%$ of total volume, while along the TSF the gas hydrate concentration is strongly variable up to zero close to the Mud Volcano Vualt. This suggests that the gas hydrate reservoir is strongly controlled by the tectonics, expressed by transtensive and compressive faults bordering the reservoir.

The relation between gas hydrate presence and tectonics is highlighted by the analysis of the BSR trend and its relationship with geological features (faults, mud volcano, slumps; Figure 4). The BSR depth is strongly variables along the margin and reaches the maximum thickness of $750 \mathrm{~m}$ (see black arrows in Figure 8) around the seismic line 197213. Comparing the map of possible gas hydrate thickness and the structural model, a possible interaction between the TFS1 and the deepening of the BSR can be supposed. The presence of deep fault-controlled canyons, affecting the slope from the shelf 
break to the middle part (Figure 4), can guide huge quantities of cold and dense turbiditic currents coming from the continental shelf. During the past, this part of margin has experienced intense turbiditic flows which have favoured the deposition of cold sediments on the top sedimentary prism. Events confirmed by the erosion affecting the upper slope, recorded in the SE part of the seismic line I97209 (Figure 3), that could be associated to the ice sheet advance to the shelf edge during the last glacial maximum $[32,52,53]$. Thus, the high BSR depth at the north of the TFS1 can be justified by higher input of cold sediments, filling the intra-slope basin (see Figure 5), that locally decrease the thermal field deepening the base of the hydrate stability zone [54].

High resolution morpho-bathymetric image reveals the presence of a well defined slump scars, located within to the SW side of the reservoir (see white arrow in Figure 4), in an area characterized by a seafloor dipping of about $3.6^{\circ}$. This value is lower than a critical angle for normal compacted terrigenous sediments, usually characterized by an inner shear strength angle (or critical angle) ranging between $15^{\circ}$ and $20^{\circ}$ [55]. Reference [56] suggests that large submarine mass movements can be triggered by some mechanisms, that are: (1) build up of excess pore pressure due to high sedimentation rate; (2) earthquakes; (3) seepage of shallow methane gases; (4) oversteepening; and (5) erosion at the toe of the slope. In the investigated area, the slump scars are located between the two main branches of the active TFS1. This suggests that tectonic activity, responsible of significant earthquakes, combined with gas presents within pore space sediments, could have triggered the observed slumps.

Lateral gas phase changes are supported by lateral seismic velocity changes and BSR lateral discontinuity. The local discontinuity of the BSR along seismic lines could be in some part related to the horizontal resolution [45] that results $240 \mathrm{~m}$. This value is obtained assuming a dominant frequency of $40 \mathrm{~Hz}$, an average root-mean square velocity of $1700 \mathrm{~m} \cdot \mathrm{s}^{-1}$ at the BSR, and a BSR depth of 2,700 m. In the western portion of the gas hydrate reservoir, around the s-FS (see Figure 3 and 4), the BSR depth from the seafloor (Figure 8) results from 450 to $600 \mathrm{~m}$. This trend is due to the missing around the fault system of a strong and continuous BSR that could have generated a misinterpretation on the seismic lines.

Along the TFS (Figure 4) the possible gas hydrate thickness (Figure 8) results are anomalously low (about $375 \mathrm{~m}$; see white arrow in Figure 8). This trend can be associated to the presence of the Mud Volcano Vualt. In proximity of this structure, the shallow BSR and the low gas hydrate concentration (Figure 7) can be correlated to intense fluid fluxes, probably guided by the TFS. This hypothesis is confirmed by fluid or/and gas fluxes recorded by chirp data and located along the side of the mud volcano close to a submarine slide. This relation between fluid outflow, slumps and mud volcano are well discussed in [30]. Moreover, this hypothesis is supported by laboratory experiments and direct observation in different studied areas, indeed some authors suggest that intense hot fluid fluxes change the thermodynamic of sediments moving up the base of gas hydrate stability zone $[16,17]$. This model of fluid escapes can be applied to the Mud Volcano Vault. It is important to underline that the presence of a strong BSR in the seismic profile 197214 (across the mud volcano) can be justified assuming a large gas accumulation at the base of the hydrate layer, as already highlighted by other authors [6,57,58]. Probably, the free gas can accumulate because the pore space of a thin layer of sediments above the BSR are partially filled by gas hydrate that acts as seal. The presence of 
the free gas zone and absence of gas hydrate was already observed by several authors [17,59] in similar environment.

In addition, the estimated geothermal gradient close to the volcano shows values greater than $40{ }^{\circ} \mathrm{C} / \mathrm{km}$ (black thick arrow in Figure 9), resulting higher than the central area, characterized by an average geothermal gradient of $37.5^{\circ} \mathrm{C} / \mathrm{km}$ (unmasked area). Moving to the continental margin, where the BSR is only locally present, lower geothermal gradient values $\left(35-37.5^{\circ} \mathrm{C} / \mathrm{km}\right.$ ) prevail (Figure 9).

Finally, a 3D model of gas hydrate concentration from the seafloor to the BSR was obtained. This model takes into account a space divided into cells, from seafloor to BSR, and the gas hydrate amount was estimated within cells. Thus, the estimated total volume of hydrate, fin the area $\left(600 \mathrm{~km}^{2}\right)$ where the interpolation is reliable, is $16 \times 10^{9} \mathrm{~m}^{3}$. Considering that the gas hydrate concentration is affected by errors that could be equal to about $\pm 25 \%$, as deduced by sensitivity tests $[44,48]$ and by error analysis related to the interpolation procedure (Figure 2). The estimate amount of gas hydrate can varies in a range of $12 \times 10^{9}-20 \times 10^{9} \mathrm{~m}^{3}$. Moreover, considering that $1 \mathrm{~m}^{3}$ of gas hydrate corresponds to $140 \mathrm{~m}^{3}$ of free gas in standard conditions, the total free gas trapped in this reservoir is in a range of $1.68 \times 10^{12}-2.8 \times 10^{12} \mathrm{~m}^{3}$. This estimation does not take into account the free gas contained within pore space below the hydrate layer, so this values could be underestimated.

\section{Conclusions}

The applied procedure allows us to characterize the gas hydrate reservoir, presents offshore Antarctic Peninsula, and draws the following conclusions:

- A complex structural setting of the sedimentary prism and the gas hydrate reservoir was defined by the structural interpretation of the depth migrated seismic images. TFS1 and TFS, characterized by transtensive and compressive movements respectively, border the morphological high corresponding to the central part of the reservoir. Moreover, a secondary fault system (s-FS), probably controlled by TFS1, borders the western side of the reservoir.

- The source of a gravitational instability, well recognised on the morpho-bathymetry image, is associated to the tectonic activity of a fault segment (part of the TFS1) and it likely to be favoured by fluid content coming from gas system.

- The gas hydrate reservoir is characterized by a regional geothermal field of about $37.5^{\circ} \mathrm{C} / \mathrm{km}$. As expected, the geothermal gradient shows a slow increase from the inner to the frontal part of the prism. Some local high values (about $40{ }^{\circ} \mathrm{C} / \mathrm{km}$ ) are associated to the mud volcano presences.

- The BSR and the gas hydrate distribution within sediments are strongly controlled by tectonics. High gas concentrations are detected in the central part of the reservoir, where not faults deformation affects the sediments.

- The 3D gas hydrate volume was estimated; the potentiality results in a range of $12 \times 10^{9}-20 \times 10^{9} \mathrm{~m}^{3}$; thus, the free gas volume in standard condition results a range of $1.68 \times 10^{12}-2.8 \times 10^{12} \mathrm{~m}^{3}$.

\section{Acknowledgements}

Thanks to the PNRA program that partially support this project. A special thanks to Daniela Accettella who has processed the multibeam data. 


\section{References and Notes}

1. Sloan, E.D., Jr. Clathrate hydrates of Natural Gases; Marcel Dekker, Inc.: New York, NY, USA, 1998; p. 705.

2. Shipley, T.H.; Houston, M.H.; Buffler, R.T.; Shaub, F.J.; McMillen, K.J.; Ladd, J.W.; Worzel, J.L. Seismic evidence for widespread possible gas hydrate horizons on continental slopes and rises. AAPG Bulletin 1979, 63, 2204-2213.

3. Collet, T.S.; Dallimore, S.R. Permafrost-Associated Gas Hydrate. In Natural Gas Hydrate in Oceanic and Permafrost Environments; Max, D., Ed.; Kluwer Academic Publishers: Dordrecht, The Netherlands, 2000; pp. 43-60.

4. Ewing, J.J.; Hollister, C.H. Regional aspects of deep sea drilling in the western North Atlantic. DSDP 1972, 11, 951-973.

5. MacKay, M.E.; Jarrard, R.D.; Westbrook, G.K.; Hyndman, R.D. Origin of bottom simulating reflectors: Geophysical evidence from the Cascadia accretionary prism. Geology 1994, 22, 459-462.

6. Holbrook, W.S.; Hoskins, H.; Wood, W.T.; Stephen, R.A.; Lizarralde, D. Methane Hydrate and Free Gas on the Blake Ridge from Vertical Seismic Profiling. Science 1996, 273, 1480-1483.

7. Kvenvolden, K.A. Methane hydrate-A major reservoir of carbon in the shallow geosphere? Chem. Geol.1988, 71, 41-51.

8. Singh, S.C.; Minshull, T.A.; Spence, G.D. Velocity structure of a gas hydrate reflector. Science 1993, 260, 204-207.

9. Milkov A.V. Global estimates of hydrate-bound gas in marine sediments: How much is really out there? Earth Sci. Rev. 2004, 66, 183-197.

10. Mienert, J.; Posewang, J.; Baumann, M. Gas hydrates along the northeastern Atlantic Margin; possible hydrate-bound margin instabilities and possible release of methane. In Gas Hydrates; Relevance to World Margin Stability and Climate Change; Henriet, J.P., Mienert, J., Eds.; Geological Society Special Publication: London, UK, 1998; Volume 137, pp. 275-291.

11. Kastner, M. Gas hydrate in convergent margins: formation, occurrence, geochemistry, and global significance. In Natural Gas Hydrates: Occurrence, Distribution, and Detection; Paull, C.K., Dillon, W.P., Eds.; American Geophysical Union: Washington, DC, USA, 2001; pp. 67-86.

12. Archer, D.; Buffett, B.; Brovkinc, V. Ocean methane hydrates as a slow tipping point in the global carbon cycle. Geophysics 2008, 106, 1-6.

13. Haq, U.B. Gas hydrates: Greenhouse Nightmare? Energy Panacea or Pipe Dream? Geol. Soc. Am. 1998, 8, 1-6.

14. Sloan, E.D., Jr. Fundamental principles and applications of natural gas hydrates. Nature 2003, 426, 353-363.

15. Natural Gas Hydrates: Occurrence, Distribution, and Detection (Geophysical Monograph); Paull, C.K., Dillon, W.P., Eds.; American Geophysical Union: Washington, DC, USA, 2001; Volume 124.

16. $\mathrm{Xu}, \mathrm{W}$.; Ruppel, G. Predicting the occurrence, distribution, and evolution of methane gas hydrate in porous marine sediments. J. Geophys. Res. 1999, 104, 5081-5095. 
17. Roberts, H.H.; Hardage, B.A.; Shedd, W.W.; Hunt, J., Jr. Seafloor reflectivity-An important seismic property for interpreting fluid/gas expulsion geology and the presence of gas hydrate. Lead. Edge 2006, 25, 620-628.

18. Lin, C.C.; Lin, A.T.S.; Liu, C.S.; Chen, G.Y.; Liao, W.Z.; Schnurle, P. Geological controls on BSR occurrences in the incipient arc-continent collision zone off southwest Taiwan. Mar. Pet. Geol. 2008, 26, 1118-1131.

19. Milkov, A.V. Worldwide distribution of submarine mud volcanoes and associated gas hydrates. Mar. Geol. 2000, 167, 29-42 and references therein.

20. Haacke, R.R.; Hyndman, R.D.; Park, K.P.; Yoo, D.G.; Stoian, I.; Schmidt, U. Migration and venting of deep gases into the ocean through hydrate-choked chimneys offshore Korea. Geology 2009, 37, 531-534.

21. Ussler, W., III; Paull, C.K. Ion exclusion associated with marine gas hydrate deposits. In Natural Gas Hydrates: Occurrence, Distribution, and Detection; Paull, C.K., Dillon, W.P., Eds.; American Geophysical Union: Washington, DC, USA, 2001; Volume 124, pp. 41-51.

22. Malinverno, A.; Kastner, M.; Torres, M.E.; Wortmann, U.G. Gas hydrate occurrence from pore water chlorinity and downhole logs in a transect across the northern Cascadia margin (Integrated Ocean Drilling Program Expedition 311). J. Geophys. Res. 2008, 113, B08103.

23. Tinivella, U.; Accaino, F. Compressional velocity structure and Poisson's ratio in marine sediments with gas hydrate and free gas by inversion of reflected and refracted seismic data (South Shetland Islands, Antarctica). Mar. Geol. 2000, 164, 13-27.

24. Tinivella, U. The seismic response to overpressure versus gas hydrate and free gas concentration. J. Seism. Explor. 2002, 11, 283-305.

25. Ojha, M.; Sain, K. Appraisal of gas-hydrate/free-gas from VP/VS ratio in the Makran accretionary prism. Mar. Pet. Geol. 2008, 25, 637-644.

26. Tinivella, U. A method for estimating gas hydrate and free gas concentrations in marine sediments. Boll. Geofis. Teor. Appl. 1999, 40, 19-30.

27. Ecker, C.; Dvorkin, J.; Nur, A. Estimating the amount of gas hydrate and free gas from marine seismic data. Geophysics 2000, 65, 565-573.

28. Chand, S.; Minshull, T.A.; Gei, D.; Carcione, M.J. Elastic velocity models for gas-hydrate-bearing sediments-a comparison. Geophys. J. Int. 2004, 159, 573-590.

29. Lee, W.M.; Waite, W.F. Estimating pore-space gas hydrate saturations from well logacoustic data. Geochem. Geophys. Geosyst. 2008, 9, 1-8.

30. Tinivella, U.; Accaino, F.; Della Vedova, B. Gas hydrates and active mud volcanism on the South Shetland continental margin, Antarctic Peninsula. Geo-Mar. Lett. 2008, 28, 97-106.

31. Pankhurst, R.J. The Paleozoic and Andean magmatic arcs of West Antarctica and southern South America. In Plutonism from Antarctica to Alaska; Kay, S.M., Rapela, C.W., Eds.; Geological Society of Amer: Boulder, CO, USA, 1990; Volume 241; pp. 1-7.

32. Larter, R.D.; Barker, P.F. Effects of ridge crest-trench interaction on Antarctic-Phoenix spreading: Forces on a young subducting plate. J. Geophys. Res. 1991, 96, 19583-19607.

33. GRAPE Team. Preliminary results of seismic reflection investigations and associated geophysical studies in the area of the Antarctic Peninsula. Antarct. Sci. 1990, 2, 223-234. 
34. Kim, Y.; Kim, H.S.; Larter, R.D.; Camerlenghi, A.; Gambôa, L.A.P.; Rudowski, S. Tectonic deformation in the upper crust and sediments at the South Shetland Trench. In Geology and Seismic Stratigraphy of the Atlantic Margin; Cooper, A.K., Barker, P.T., Brancolini, G., Eds.; American Geophysical Union: Washington, DC, USA, 1995; Volume 68, pp. 157-166.

35. Jin, Y.K.; Larter, R.D.; Kim, Y.; Nam, S.H.; Kim, K.J. Post-subduction margin structures along Boyd Strait, Antarctic Peninsula. Tectonophysics 2002, 346,187-200.

36. Dietrich, R.; Rülke, A.; Ihde, J.; Lindner, K.; Miller, H.; Niemeier, W.; Schenke, H.W.; Seeber, G. Plate kinematics and deformation status of the Antarctic Peninsula based on GPS. Global Plan Change 2004, 42, 313-321.

37. Extract Topography or Gravity Data from Global 1-Minute Grids in ASCII XYZ-Format, version 13.1 for Topography; version 18.1 for Gravity, 2009. Available online: http://topex.ucsd.edu/cgibin/get_data.cgi (accessed on 30 December 2010)

38. Thomas, C.; Livermore, R.; Pollitz, F. Motion of the Scotia Sea Plates. Geophys. J. Int. 2003, 155, 789-804.

39. Barker, P.F. The Cenozoic subduction history of the Pacific margin of the Antarctic Peninsula: Ridge crest-trench interactions. Geol. Soc. Lond. J. 1982, 139, 787-801.

40. Lawver, L.A.; Keller, R.A.; Fisk, M.R.; Strelin, J.A. Bransfield Strait, Antarctic Peninsula: Active extension behind a dead arc. In Backarc Basin: Tectonics and Magmatism; Taylor, B., Ed.; Plenum Press: New York, NY, USA, 1995; pp. 315-342.

41. Barker, P.F.; Dalziel, I.W.D. Progress in geodynamics in the Scotia Arc region. In Geodynamics of the Eastern Pacific Region, Caribbean and Scotia Arcs; Cabre, R., Ed.; American Geophysical Union: Washington, DC, USA, 1983; Volume 9, pp. 137-170.

42. Lodolo, E.; Camerlenghi, A.; Madrussani, G.; Tinivella, U.; Rossi, G. Assessment of gas hydrate and free gas distribution on the South Shetland margin (Antarctica) based on multichannel seismic reflection data. Geophys. J. Int. 2002, 148, 103-119.

43. Tinivella, U.; Lodolo, E.; Camerlenghi, A.; Boehm, G. Seismic tomography study of a bottom simulating reflector off the South Shetland Islands (Antarctica). Geol. Soc. Lond. Special Publ. 1998, 137, 141-151.

44. Tinivella, U.; Loreto, M.F.; Accaino, F. Regional versus detailed velocity analysis to quantify hydrate and free gas in marine sediments: the south shetland margin case study. Soc. Geol. Lond. Special Publ. 2009, 319, 103-119.

45. Yilmaz, O. Seismic Data Analysis: Processing, Inversion and Interpretation of Seismic Data. Series: Investigation in Geophysics. SEG 2001, 10, 2077.

46. Liu, Z.; Bleisten, N. Migration velocity analysis: Theory and an iterative algorithm. Geophysics 1995, 60, 142-153.

47. Wessel, P.; Smith, W.H.F. Free software helps map and display data. Eos Trans. Am. Geophys. Union 1991, 72, 441.

48. Tinivella, U.; Accaino, F.; Camerlenghi, A. Gas hydrate and free gas distribution form inversion of seismic data on the South Shetland margin (Antarctica). Mar. Geophys. Res. 2002, 23, 109-123. 
49. Hamilton, E.L. $V_{\mathrm{p}} / V_{\mathrm{s}}$ and Poisson's ratios in marine sediments and rocks. J. Acoust. Soc. Am. 1979, 66, 1093-1101.

50. Hamilton, E.L. Variations of density and porosity with depth in deep-sea sediments. J. Sediment. Petrol. 1976, 46, 280-300.

51. Cohen, J.K.; Stockwell, J.W. CWP/SU: Seismic Unix release 35: A Free Package for Seismic Research and Processing; Center for Wave Phenomena, Colorado School of Mines: Golden, CO, USA, 2001.

52. Bart, P.J.; Anderson, J.B. Seismic expression of depositional sequences associated with expansion and contraction of ice sheets on the northwestern Antarctic Peninsula continental shelf. Geol. Soc. Lond. Special Publ. 1996, 117, 171-186.

53. Hillenbrand, C.-D.; Benetti, S.; Ehrmann, W.; Larter, R.D.; Cofaigh, C.Ó.; Dowdeswell, J.A.; Grobe, H.; Graham, A.G.C. Glacial dynamics of the West Antarctic Ice Sheet in the southern Bellingshausen Sea during the last glacial cycle. In Antarctica: A Keystone in a Changing World, Proceedings of the 10th International Symposium on Antarctic Earth Sciences, Santa Barbara, CA, USA, 2007; Cooper, A.K., Barrett, P., Stagg, H., Storey, B., Stump, E., Wise, W., and the 10th ISAES Editorial Team, Eds.; The National Academies Press: Washington, DC, USA, 2008.

54. Ganguly, N.; Spence, G.D.; Chapman, N.R.; Hyndman, R.D. Heat flow variations form bottom simulating reflectors on the Cascadia margin. Mar. Geol. 2000, 164, 53-68.

55. Dott, R.H., Jr. Dynamics of subaqueus gravity depositional processes. AAPG Bulletin 1963, 47, 104-128.

56. Dimakis, P.; Elverhoi, A.; Hoeg, K.; Solheim, A.; Harbitz, C.; Laberg, J.S.; Vorren, T.O.; Marr, J. Submarine slope stability on high-latitude glaciated Svalbard-Barents Sea margin. Mar. Geol. 2000, 162, 303-316.

57. Murphy, W.F. Acoustic Measures of Partial Gas Saturation in Tight Sandstones. JGR 1989, 89, 1549-1559.

58. Ewing, J.J.; Hollister, C.H. Regional aspects of deep sea drilling in the western North Atlantic. DSDP 1972, 11, 951-973.

59. Milkov, A.V.; Sassen, R. Economic geology of offshore gas hydrate accumulations and provinces. Mar. Petrol. Geol. 2002, 19, 1-11.

(C) 2010 by the authors; licensee MDPI, Basel, Switzerland. This article is an open access article distributed under the terms and conditions of the Creative Commons Attribution license (http://creativecommons.org/licenses/by/3.0/). 